\title{
FEED UTILIZATION EFFICIENCY AND GROWTH PERFORMANCE IN ROHU, LABEO ROHITA (HAMILTON, 1822), FINGERLINGS FED YEAST EXTRACT POWDER SUPPLEMENTED DIETS
}

\author{
Koushik GHOSH ${ }^{1}$, Sukanta Kumar $S E N^{2}$, Arun Kumar $R A Y^{1 *}$ \\ ${ }^{1}$ Fisheries Laboratory, Department of Zoology, ${ }^{2}$ Microbiology Laboratory, Department of Botany; \\ Visva-Bharati University, Santiniketan, West Bengal, India
}

Ghosh K., Sen S.K., Ray A.K. 2005. Feed utilization efficiency and growth performance in rohu, Labeo rohita (Hamilton, 1822), fingerlings fed yeast extract powder supplemented diets. Acta Ichthyol. Piscat. 35 (2): 111-117.

Background. Yeast extract powder (YEP) is a rich source of several B vitamins and is used mainly in bacterial culture. In the present study, the effect of dietary supplementation of YEP on growth, feed conversion, nutrient ADC, body composition, and digestive enzyme profile of rohu, Labeo rohita (Hamilton, 1822) fingerlings was evaluated.

Materials and methods. Rohu fingerlings (mean individual weight $1.76 \pm 0.15 \mathrm{~g}$ ) were fed, twice daily, fish meal-based $35 \%$ protein diets supplemented with YEP $(0.1 \%, 0.2 \%, 0.3 \%, 0.4 \%$, and $0.5 \%$ on dry matter basis) for 75 days at $3 \%$ of body weight, in triplicate. Fish performance in terms of growth, apparent nutrient digestibility, and whole body composition was studied. The intestinal protease and amylase activities were also determined in rohu fingerlings fed YEP-supplemented diets. Microbial cultures of the intestinal mucosa of the fish in all dietary treatments were carried out after the feeding trial in soybean-casein digest agar (TSA), gelatin-peptone (GP), starch (ST) and carboxymethylcellulose (CMC) plates, separately, to determine the protease-, amylase, and cellulase-producing capacities (qualitative) of the isolated organisms.

Results. The fish fed YEP-supplemented diets exhibited better growth than the control up to $0.2 \%$ level. YEP at $0.1 \%$ level resulted in the best performance of the fish in terms of per cent weight gain, SGR, FCR, and PER, followed by the $0.2 \%$ level. YEP led to higher deposition of protein and lower deposition of lipid in the carcass. The intestinal protease activity was highest in the fish fed $0.1 \%$ yeast, followed by $0.2 \%$. Protease-producing capacity of the intestinal bacterial flora in the in vitro cultures followed the same trend.

Conclusion. It appears therefore that YEP in the diets might have some effect on the gut microflora by supplying additional digestive enzymes leading to better nutrient utilization.

Key words: yeast extract powder, bacterial flora, digestive enzymes, feed utilization, growth, rohu, Labeo rohi$t a$ fingerlings, fish

\section{INTRODUCTION}

Feed cost is considered to be the highest recurrent cost in aquaculture, often ranging from $30 \%$ to $60 \%$, depending on the intensity of the operation (De Silva and Anderson 1995). Any reduction in feed costs either through diet development, improved husbandry, or other direct or indirect means is therefore crucial to the development and wellbeing of the industry. A number of nutritionally balanced feed formulations have already been tested successfully in laboratory and field trials. Though the proper growth of fish depends mainly upon the quantity and quality of food having all the essential nutrients, there is a limit of maximum growth for fish, even if optimum amount of balanced nutrients is provided. Beyond this physiological limit, growth may be possible either by genetic manipulation or by administration of growth promoters (Matty 1986). In compliance with this, a number of feed additives have been used (Das and Krishnamurthy 1959 a, b, Sen 1972, Swain et al. 1996). Das (1965) and Jhingran (1983) postulated that yeast, a rich source of vitamin B complex, plays important roles in promoting survival of carp hatchlings. Mahajan and Sharma (1976) observed that a combination of vitamin B complex and yeast gives the best results in terms of survival and growth of Cyprinus carpio and Labeo rohita. Yeast alone or in combination with vitamins $\mathrm{B}_{12}$ and $\mathrm{B}$ complex also significantly enhanced survival rates.

Brewer's yeast is a by-product of the brewing industry and constitutes the basic raw material for the manufacture

\footnotetext{
* Correspondence: Prof. Dr Arun Kumar Ray, Fisheries Laboratory, Visva-Bharati University, Santiniketan-731 235, West Bengal, India, Phone/Fax: (+91)-3463-261268, e-mail: arun_rayl@rediffmail.com
} 
of yeast extract. Yeast extract consists of protein and other intracellular constituents extracted by the process of autolysis. It is a rich source of B vitamins and is used to supply these factors in bacterial cultures. Yeast extract serves as an extracellular stimulant of bacterial growth and is frequently used in culture media (Salle 1974).

The present study was designed to evaluate the effects of yeast extract powder (YEP) as dietary supplementation in five isonitrogenous diets for rohu, Labeo rohita, fingerlings, and also to assess the role of yeast extract for production of proteolytic and amylolytic enzymes by gut bacterial flora.

\section{MATERIALS AND METHODS}

Diet preparation. Six isonitrogenous diets (RD, D1, D2, D3, D4, and D5) were prepared (Table 1). The experimental diets (D1 to D5) were supplemented with YEP (Loba Chemie Pvt. Ltd., India) in increasing amounts $(0.1 \%, 0.2 \%$, $0.3 \%, 0.4 \%$, and $0.5 \%$ on dry matter basis, respectively).

Dietary ingredients were finely powdered and sieved (pore diameter $<400 \mu \mathrm{m}$ ). The required ingredients were mixed thoroughly with lukewarm water to make a dough, using $0.5 \%$ carboxymethylcellulose as a binder. A vitamin-mineral mixture (Vitaminetes Forte, Roche India Ltd., India) was added to the diets before pelletization. Chromic oxide $(1 \% \mathrm{w} / \mathrm{w})$ was added to each formulated diet as an external digestibility marker. The dough was steam-cooked and then passed through an electrically operated semiautomatic pelletizer (pellet diameter 1.5 $\mathrm{mm}$ ). The pellets were dried at $60^{\circ} \mathrm{C}$, packed in air-tight plastic bags and stored in refrigerator.

Experimental design. The feeding trial was conducted under laboratory conditions, in 18 glass aquaria, each containing $90 \mathrm{~L}$ of water, for 75 days, with continuous aeration. Rohu, Labeo rohita, fingerlings were obtained from a local fish seed dealer and acclimatised for 15 days. The fingerlings (mean individual weight of the 270 fingerlings $1.76 \pm 0.15 \mathrm{~g}$ ) were randomly distributed in the glass aquaria at a stocking density of 15 fish per aquarium with three replicates for each dietary treatment. The fish were fed twice daily: at 0800 and $1200 \mathrm{~h}$, at a feeding rate of $3 \%(\mathrm{w} / \mathrm{w})$ of the total body weight per day. The daily ration was adjusted every tenth day after weighing the fish from each replicate. The uneaten feed was siphoned off 6 hours after each feeding, and oven dried at $100^{\circ} \mathrm{C}$ for $24 \mathrm{~h}$ to calculate the feed conversion ratio. The uneaten feeds remained almost intact due to the binder. The faecal samples released by the fish were collected daily from each aquarium by pipetting (Spyridakis et al. 1989). The ovendried $\left(60^{\circ} \mathrm{C}\right)$ faecal samples were analysed for digestibility estimation. Five fish from each aquarium were sampled at the termination of the feeding experiment; they were homogenised and analysed for whole body composition (on wet weight basis). The ranges of water quality parameters were: temperature $13-22^{\circ} \mathrm{C}$; $\mathrm{pH}$ 6.2-7.4; and dissolved oxygen $5.8-7.7 \mathrm{mg} \cdot \mathrm{L}^{-1}$.

Chemical analyses and data collection. The feed ingredients, experimental diets, and faecal samples were analysed for proximate composition (Anonymous 1990) as follows: moisture content, by oven-drying for $24 \mathrm{~h}$ at $105^{\circ} \mathrm{C}$; crude protein $(\mathrm{N} \times 6.25)$, by the micro-Kjeldahl digestion and distillation after acid digestion, using a Tecator Digestion System together with Kjeltec 1026 Distilling Unit (Tecator, Sweden); lipids, by extracting the residue with petroleum ether $\left(40-60^{\circ} \mathrm{C}\right)$ for $8 \mathrm{~h}$ in a Soxhlet apparatus; crude fibre, as loss on ignition of dried lipid-free residues after digestion with $1.25 \% \mathrm{H}_{2} \mathrm{SO}_{4}$ and $1.25 \% \mathrm{NaOH}$; ash, by ignition of samples at $550^{\circ} \mathrm{C}$ in a muffle furnace to constant weight. Nitrogen-free extract (NFE) was computed by taking the sum of values for crude protein, crude lipid, ash, crude fibre, and moisture and subtracting this from 100 (Maynard et al. 1979). Chromic oxide levels in the diets and in the faecal samples were estimated spectrophotometrically (Bolin et al. 1952). Proximate analyses of whole body were done (Anonymous 1990) both at the beginning and termination of the feeding experiment. The water quality parameters were monitored as recommended by the APHA (Anonymous 1985).

The fish from each experimental set were dissected on an ice tray to remove the intestine in order to determine the digestive enzyme activities prior to commencement and at the termination of the feeding trials. $\alpha$-Amylase was determined quantitatively following Bernfeld (1955). Protease activity was measured as described by Moore and Stein (1948), using bovine serum albumin as substrate.

Average live weight gain (\%), specific growth rate (SGR; \% day ${ }^{-1}$ ), feed conversion ratio (FCR), and protein efficiency ratio (PER) were calculated using standard methods (Steffens 1989).

The apparent digestibility coefficients (ADC) of nutrients were calculated according to Cho et al. (1982), using the following formula:

$$
\mathrm{ADC}=100-100 \times \frac{\% \mathrm{Cr}_{2} \mathrm{O}_{3} \text { in diet }}{\% \mathrm{Cr}_{2} \mathrm{O}_{3} \text { in faeces }} \frac{\times \% \text { Nutrient in faeces }}{\% \text { Nutrient in diet }}
$$

Microbial culture. Microbial cultures of the intestinal mucosa collected from the fish of all six dietary groups were carried out for bacterial isolation after completion of the experiment, following the method described by Bairagi et al. (2002). For this purpose, the homogenate of the intestinal mucosa was used after five serial 1:10 dilutions (Beveridge et al. 1991). Samples (0.1 mL) were taken from each dilution and poured aseptically within laminar flow on sterilised soybean casein digest agar (TSA), gelatin-peptone (GP), starch (ST), and carboxymethylcellulose (CMC) plates, separately one for each aerobic bacteria type. The culture plates were incubated at $37 \pm 1^{\circ} \mathrm{C}$ for $24 \mathrm{~h}$. The colony forming units $\left(\mathrm{CFU} \cdot \mathrm{g}^{-1}\right)$ were determined and identified by external morphology, then transferred to the culture plates (with the same medium) to check their purity. The single colony was finally transferred to slants (TSA) as pure culture. These steps were conducted aseptically under laminar flow as well.

The organisms isolated from each dietary group were tested for protease- and amylase-producing capacities 
(qualitative). The intensity of transparent zone (halo) produced by flooding the GP plates with protein-precipitating reagent and ST plates with Lugol's iodine indicated the protease-and amylase-producing capacities, respectively.

Culture media composition. The composition of the media used were as follows: TSA medium $\left(\mathrm{g} \cdot \mathrm{L}^{-1}\right)$ : casein (15), papaic digest of soybean meal (5), $\mathrm{NaCl}(5)$, agar (20); GP medium $\left(\mathrm{g} \cdot \mathrm{L}^{-1}\right)$ : Lablemco (3), peptone (5), gelatin (4), agar (20); ST medium (g · L $\left.{ }^{-1}\right)$ : $\left(\mathrm{NH}_{4}\right)_{2} \mathrm{SO}_{4}(2), \mathrm{KH}_{2} \mathrm{PO}_{4}$ (4), $\mathrm{Na}_{2} \mathrm{HPO}_{4}$ (4), $\mathrm{MgSO}_{4} \cdot 7 \mathrm{H}_{2} \mathrm{O}$ (0.2), $\mathrm{CaCl}_{2}$ (0.001), $\mathrm{FeSO}_{4} \cdot 7 \mathrm{H}_{2} \mathrm{O}$ (0.004), starch (1.0), agar (15); CMC medium $\left(\mathrm{g} \cdot \mathrm{L}^{-1}\right)$ : ST medium with starch substituted by CMC.

Statistical treatment. Analysis of variance (ANOVA) followed by Duncan's multiple range test (Duncan 1955) was employed to find out which group of the fish differed significantly from the other with respect to growth, whole body composition, nutrient digestibility, profiles of digestive enzymes, and general performance.

\section{RESULTS}

Growth performance and feed utilization. Data pertaining to fish performance and survival are presented in Table 2. Maximum weight gain was obtained with diet D1, followed by D2. Diets D1 (0.1\% YEP) and D2 $(0.2 \%$ YEP) resulted in a significantly higher growth, lower feed conversion ratio (FCR), higher specific growth rate
(SGR\%), and higher protein efficiency ratio (PER), compared to other experimental diets. The apparent digestibility (ADC) of protein, lipids, and dry matter showed a decreasing trend with increasing levels of inclusion of YEP. The digestibility of dry matter and protein was better for diet D1, followed by D2. However, there was no significant difference $(P<0.05)$ in protein digestibility among diets D1, D2, and D3 and in lipid digestibility among diets RD, D1, and D2. The lowest value of digestibility of all the nutrients was recorded with diet D5 (the highest level of supplementation).

Proximate whole body composition. The whole body moisture and lipid levels decreased, while the protein and ash contents increased, from the initial values in all experimental groups. Diet D1 resulted in maximum deposition of protein, followed by diet D2. The control diet (RD) resulted in maximum deposition of fat in the carcass, which was significantly $(P<0.05)$ higher than that in all other dietary treatments. The ash content of the fish fed diets D4 and D5 was significantly higher than that obtained with RD and other experimental diets.

Aerobic bacterial counts. The bacterial population was determined in selective medium in terms of colony forming unit per $\mathrm{g}\left(\mathrm{CFU} \mathrm{g}^{-1}\right)$ of intestinal tissue (Table 3$)$. The CFUs on TSA plates and on GP plates were highest in D1 group, followed by $\mathrm{D} 2$ group. Though the amylolytic bacterial pop-

Table 1

Ingredient composition (\% dry weight) and proximate composition (on dry matter basis) of the experimental diets

\begin{tabular}{lcccccc}
\hline & \multicolumn{7}{c}{ Diet } \\
\cline { 2 - 7 } Ingredients & $\mathrm{RD}^{\mathrm{a}}$ & $\mathrm{D} 1$ & $\mathrm{D} 2$ & $\mathrm{D} 3$ & $\mathrm{D} 4$ & $\mathrm{D} 5$ \\
\hline Fish meal & 38 & 38 & 38 & 38 & 38 & 38 \\
Rice bran & 28 & 27.9 & 27.8 & 27.7 & 27.6 & 27.5 \\
Mustard oil cake & 27 & 27 & 27 & 27 & 27 & 27 \\
Sun flower oil & 2 & 2 & 2 & 2 & 2 & 2 \\
Cod liver oil & 2 & 2 & 2 & 2 & 2 & 2 \\
Vitamin and mineral premix $^{\mathrm{b}}$ & 2 & 2 & 2 & 2 & 2 & 2 \\
Chromic oxide & 1 & 1 & 1 & 1 & 1 & 1 \\
Yeast extract powder & & & & & \\
Carboxymethylcellulose (Binder) & 0.5 & 0.1 & 0.2 & 0.3 & 0.4 & 0.5 \\
Proximate composition [\%] & & & 0.5 & 0.5 & 0.5 & 0.5 \\
Moisture $_{\text {Crude protein }}$ & & & & & & \\
Crude lipid & 4.29 & 4.87 & 6.64 & 4.73 & 5.12 & 4.96 \\
Ash & 33.33 & 34.86 & 33.66 & 34.12 & 33.65 & 34.83 \\
Crude fibre & 10.52 & 10.07 & 10.27 & 10.28 & 10.32 & 10.06 \\
NFE & 13.76 & 13.70 & 13.47 & 13.76 & 14.01 & 13.48 \\
\hline
\end{tabular}

${ }^{a}$ Control diet; ${ }^{b}$ vitamin and mineral premix (Vitaminets Forte, Nicholas Piramal India Ltd., Pithampur, Madhya Pradesh, India); each $800 \mathrm{mg}$ tablet contains: vitamin A IP (as acetate) $2500 \mathrm{IU}$; thiamine mononitrate IP (vitamin B1) $2 \mathrm{mg}$; riboflavine IP (vitamin B2) $3 \mathrm{mg}$; nicotinamide IP $25 \mathrm{mg}$; pyridoxine hydrochloride IP (vitamin B6) $1.5 \mathrm{mg}$; calcium pantothenate IP $5 \mathrm{mg}$; cyanocobalamin IP (vitamin B12) $1 \mathrm{mcg}$; ascorbic acid IP (vitamin C) $50 \mathrm{mg}$; cholecalciferol IP (vitamin D3) $200 \mathrm{IU}$; $\alpha$-tocopherol acetate IP (vitamin E acetate) $10 \mathrm{mg}$; biotin USP (vitamin H) $0.05 \mathrm{vmg}$; calcium phosphate IP $208 \mathrm{mg}$; dried ferrous sulphate IP $10.62 \mathrm{mg}$; magnesium phosphate, dibasic $48 \mathrm{mg}$; manganese hypophosphate $0.6 \mathrm{mg}$; total phosphorus 44.60

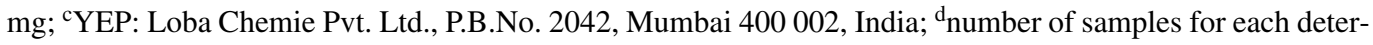
mination $=5$; ${ }^{\mathrm{e}}$ Nitrogen-free extract 
Growth performance, apparent nutrient digestibility, and carcass composition of fish fed experimental diets

Table 2 for 75 days (mean \pm standard deviation of 3 determinations)

\begin{tabular}{|c|c|c|c|c|c|c|}
\hline \multirow[b]{2}{*}{ Performance } & \multicolumn{6}{|c|}{ Diet } \\
\hline & $\mathrm{RD}^{\mathrm{a}}$ & D1 & D2 & D3 & D4 & D5 \\
\hline Initial weight $[\mathrm{g}]$ & $1.76 \pm 0.15$ & $1.76 \pm 0.15$ & $1.76 \pm 0.15$ & $1.76 \pm 0.15$ & $1.76 \pm 0.15$ & $1.76 \pm 0.15$ \\
\hline Final weight $[\mathrm{g}]$ & $3.40 \pm 0.15^{b}$ & $3.93 \pm 0.18^{a}$ & $3.81 \pm 0.04^{\mathrm{a}}$ & $3.47 \pm 0.32^{b}$ & $3.43 \pm 0.21^{\mathrm{b}}$ & $3.07 \pm 0.11^{\mathrm{c}}$ \\
\hline $\begin{array}{l}\text { Average live weight gain } \\
{[\%]}\end{array}$ & $93.33 \pm 3.84^{b}$ & $123.21 \pm 6.52^{a}$ & $115.25 \pm 5.2^{\mathrm{a}}$ & $97.39 \pm 4.3^{b}$ & $94.65 \pm 3.2^{\mathrm{b}}$ & $74.18 \pm 2.9^{\mathrm{c}}$ \\
\hline SGR $\left[\% \mathrm{~d}^{-1}\right]$ & $0.88 \pm 0.04^{\mathrm{d}}$ & $1.07 \pm 0.03^{\mathrm{a}}$ & $1.02 \pm 0.03^{\mathrm{a}}$ & $0.91 \pm 0.03^{b c}$ & $0.89 \pm 0.04^{\mathrm{cd}}$ & $0.74 \pm 0.02^{\mathrm{e}}$ \\
\hline PER & $1.31 \pm 0.04^{\mathrm{b}}$ & $1.58 \pm 0.06^{\mathrm{a}}$ & $1.54 \pm 0.07^{\mathrm{a}}$ & $1.36 \pm 0.04^{\mathrm{b}}$ & $1.32 \pm 0.03^{\mathrm{b}}$ & $1.01 \pm 0.02^{\mathrm{c}}$ \\
\hline FCR & $2.41 \pm 0.08^{b}$ & $1.83 \pm 0.06^{\mathrm{d}}$ & $1.95 \pm 1.04^{\mathrm{c}}$ & $2.31 \pm 0.09^{b}$ & $2.38 \pm 0.06^{\mathrm{b}}$ & $3.03 \pm 0.08^{\mathrm{a}}$ \\
\hline Survival [\%] & 100 & 100 & 100 & 100 & 100 & 100 \\
\hline \multicolumn{7}{|c|}{ Apparent digestibility coefficient [\%] } \\
\hline Dry matter & $46.98 \pm 1.14^{\mathrm{b}}$ & $52.26 \pm 1.91^{\mathrm{a}}$ & $50.68 \pm 1.27^{\mathrm{ab}}$ & $48.6 \pm 1.75^{b}$ & $47.22 \pm 1.47^{b}$ & $43.62 \pm 1.95^{\mathrm{c}}$ \\
\hline Protein & $80.97 \pm 3.6^{\mathrm{b}}$ & $86.26 \pm 2.47^{\mathrm{a}}$ & $85.74 \pm 2.55^{\mathrm{a}}$ & $82.78 \pm 3.18^{\mathrm{a}}$ & $80.6 \pm 2.21^{\mathrm{bc}}$ & $77.89 \pm 2.46^{\mathrm{c}}$ \\
\hline Lipid & $90.93 \pm 3.21^{\mathrm{a}}$ & $89.14 \pm 3.21^{\mathrm{a}}$ & $88.04 \pm 3.89^{\mathrm{a}}$ & $86.55 \pm 3.56^{\mathrm{ab}}$ & $81.69 \pm 2.05^{\mathrm{b}}$ & $70.91 \pm 2.38^{\mathrm{c}}$ \\
\hline \multicolumn{7}{|l|}{$\begin{array}{l}\text { Whole body composition } \\
\text { [\% wet weight] }\end{array}$} \\
\hline Protein & $14.44 \pm 0.57^{\mathrm{c}}$ & $17.16 \pm 0.62^{\mathrm{a}}$ & $16.12 \pm 0.57^{\mathrm{a}}$ & $15.2 \pm 0.63^{b}$ & $14.82 \pm 0.63^{c}$ & $13.55 \pm 0.42^{\mathrm{d}}$ \\
\hline Lipid & $6.81 \pm 0.21^{\mathrm{a}}$ & $5.37 \pm 0.22^{b}$ & $4.13 \pm 0.2^{\mathrm{c}}$ & $3.7 \pm 0.11^{\mathrm{d}}$ & $2.56 \pm 0.11^{\mathrm{e}}$ & $1.37 \pm 0.04^{\mathrm{f}}$ \\
\hline Ash & $3.56 \pm 0.14^{\mathrm{b}}$ & $3.38 \pm 0.15^{\mathrm{c}}$ & $3.18 \pm 0.09^{\mathrm{d}}$ & $3.05 \pm 0.14^{\mathrm{e}}$ & $3.96 \pm 0.17^{\mathrm{a}}$ & $3.89 \pm 0.15^{\mathrm{a}}$ \\
\hline
\end{tabular}

${ }^{\mathrm{a} C}$ Control diet; ${ }^{\mathrm{b}}$ Initial values: protein $10.28 \pm 0.39$; lipid $5.87 \pm 0.23$; ash $2.89 \pm 0.12$; values with identical superscript letters in the same row are not significantly different $(P<0.05)$

Table 3

Aerobic bacterial count ( $\mathrm{CFU} \cdot \mathrm{g}^{-1}$ intestine) in Labeo rohita fingerlings fed experimental diets for 75 days

\begin{tabular}{ccccc}
\hline \multirow{2}{*}{ Diet } & \multicolumn{4}{c}{ CFU g $^{-1}$ intestine* $^{*}$} \\
\cline { 2 - 5 } & $\begin{array}{c}\text { Bacterial count on TSA } \\
\left(\times 10^{6}\right)\end{array}$ & $\begin{array}{c}\text { Proteolytic } \\
\left(\times 10^{6}\right)\end{array}$ & $\begin{array}{c}\text { Amylolytic } \\
\left(\times 10^{3}\right)\end{array}$ & $\begin{array}{c}\text { Cellulolytic }^{4} \\
\left(\times 10^{3}\right)\end{array}$ \\
\hline RD & 1.6 & 1.3 & ND & 0.8 \\
D1 & 2.0 & 1.9 & 0.1 & 0.7 \\
D2 & 1.9 & 1.6 & 0.4 & 0.6 \\
D3 & 1.5 & 1.4 & 0.8 & 0.2 \\
D4 & 1.5 & 1.4 & 0.3 & 0.5 \\
D5 & 1.5 & 1.1 & 0.3 & 0.4 \\
\hline
\end{tabular}

ND, not detected; ${ }^{1}$ Soybean casein digest agar; ${ }^{2}$ on gelatin-peptone (GP) plate; ${ }^{3}$ on starch (ST) plate; ${ }^{4}$ on carboxymethylcellulose (CMC) plate; *since one culture plate was used for each bacteria type, no statistical analysis was possible for aerobic bacterial counts (CFU)

Protease and $\alpha$-amylase activity in Labeo rohita fingerlings fed experimental diets for 75 days

Table 4

\begin{tabular}{|c|c|c|c|c|}
\hline & Protease activity & & $\alpha$-Amylase activity & \\
\hline Diet & $\begin{array}{c}\text { Intestinal }^{\mathrm{a}} \\
(\mu \mathrm{g} \text { glycine } \\
\text { liberated } \mathrm{h}^{-1} \\
\left.\text { mg protein }^{-1}\right)^{\mathrm{a}}\end{array}$ & $\begin{array}{c}\text { Bacterial }^{\mathrm{c}} \\
\text { (diameter } \\
\text { of halo) } \\
{[\mathrm{mm}]}\end{array}$ & $\begin{array}{c}\text { Intestinal }^{\mathbf{b}} \\
\left(\mathrm{mg} \text { maltose liberated } \mathrm{h}^{-1} \mathrm{mg}\right. \\
\left.\text { protein }^{-1}\right)^{\mathrm{a}}\end{array}$ & $\begin{array}{c}\text { Bacterial }^{\mathrm{c}} \\
\text { (diameter of halo) } \\
{[\mathrm{mm}]}\end{array}$ \\
\hline $\mathrm{RD}$ & $22.13 \pm 0.92^{c}$ & $8.5 \pm 0.4^{5}$ & $10.15 \pm 0.34^{\mathrm{d}}$ & not detected \\
\hline D1 & $28.15 \pm 1.28^{\mathrm{a}}$ & $16.2 \pm 0.6^{\mathrm{a}}$ & $13.19 \pm 0.54^{\mathrm{ab}}$ & $4.5 \pm 0.2^{\mathrm{c}}$ \\
\hline $\mathrm{D} 2$ & $27.02 \pm 1.29^{\mathrm{a}}$ & $13.5 \pm 0.5^{\mathrm{b}}$ & $13.53 \pm 0.44^{\mathrm{a}}$ & $10.2 \pm 0.5^{\mathrm{a}}$ \\
\hline D3 & $23.89 \pm 1.05^{\mathrm{bc}}$ & $9.0 \pm 0.4^{\mathrm{c}}$ & $10.82 \pm 0.49^{\mathrm{d}}$ & $10.2 \pm 0.5^{\mathrm{a}}$ \\
\hline D4 & $24.27 \pm 1.18^{\mathrm{b}}$ & $8.5 \pm 0.3^{c}$ & $12.56 \pm 0.56^{\mathrm{bc}}$ & $8.0 \pm 0.3^{b}$ \\
\hline D5 & $22.03 \pm 1.06^{\mathrm{c}}$ & $6.2 \pm 0.2^{\mathrm{d}}$ & $12.19 \pm 0.58^{\mathrm{c}}$ & $7.5 \pm 0.2^{b}$ \\
\hline
\end{tabular}

${ }^{a}$ Initial value: $14.69 \pm 0.58$; ${ }^{\text {initial value: } 7.14 \pm 0.29}$; ${ }^{c}$ with pure culture of intestinal isolates; values with identical superscript in the same column are not significantly different $(P<0.05)$ 
ulation was not detected in RD group, it appeared in the fish fed YEP-supplemented diets and reached a peak in D3 group.

Activities of digestive enzymes. Intestinal $\alpha$-amylase and protease activities in the fish fed experimental diets are presented in Table 4 . The activities of both enzymes increased from the respective initial values in all the dietary treatments. The intestinal $\alpha$-amylase activity was highest with diet D2, while the protease activity was at a maximum with diet D1.

Bacterial enzyme producing capacity. In vitro enzyme analyses of the isolated bacterial flora from different dietary groups showed a trend identical to that evidenced by the fish intestinal enzyme activity. The organisms isolated from D1 dietary group showed a higher protease producing capacity, compared to that from other dietary groups. $\alpha$-Amylase producing capacity was higher in the bacterial flora isolated from D2 dietary group, followed by D3. The $\alpha$-amylase production by the bacterial flora isolated from the reference diet group was beyond limits of detection.

\section{DISCUSSION}

The present study indicated the rohu fingerlings fed diets supplemented with YEP at $0.1 \%$ and $0.2 \%$ levels to show the best growth performance, FCR, and PER, compared to the fish fed the control diet without YEP supplementation (RD). Diets D3 and D4 with $0.3 \%$ and $0.4 \%$ yeast extract supplementation, respectively, resulted in a relatively better growth of the fish, the growth indices being not significantly different from those produced by the reference diet. The diet with $0.5 \%$ YEP (D5) resulted in a lower growth rate. In the present study, the growth rate of rohu fingerlings was low compared to the fish growth under natural and farm conditions. A similar trend of growth was also reported in other nutritional experiments involving major Indian carps, including rohu (Ravi and Devaraj 1991, Benkappa and Varghese 2003, Ramachandran and Ray 2004). A possible explanation for this lower growth rate could be that the major Indian carps are sensitive to environmental conditions and do not attain maximum growth in a confined environment, compared with other hardy species, such as tilapia and common carp (Benkappa and Varghese 2003). Singh et al. (1986) observed that yeast-containing diets are more readily acceptable by rohu fingerlings. Those authors also found that yeast increased the rate of feed intake and conversion efficiency in rohu fry. Charlon and Bergot (1984) achieved survival higher than $89 \%$ and good growth in carp larvae fed exclusively dry diets enriched with yeast powder and pork/beef freeze-dried liver. Dabrowski et al. (1984) recorded significant growth in coregonid larvae fed two different yeast-based diets. Swain et al. (1996) recorded the best performance of mrigal, Cirrhinus mrigala, fry in terms of growth and nutrient utilization, with a diet supplemented with $0.15 \%$ of a probiotic, Bioboost Forte (containing live culture of the yeast Saccharomyces cerevisiae and live culture of Lactobacillus coagulans). There is, however, no report on effects of yeast extract supple- mentation on the growth and survival of Labeo rohita fingerlings. It has been reported that yeast in the diets improves feed efficiency, organic phosphorus (phytic acid) utilization, and fibre digestion (Pollman 1986). In the present study, apparent digestibility of dry matter, protein, and lipids showed a trend similar to that found for the growth performance.

In the present experiment, an increase in carcass protein was noticed with increasing level of yeast extract in the diets up to $0.4 \%$ level. The values were higher than that of the reference diet. The maximum carcass protein was recorded in the fish fed diet D1 supplemented with $0.1 \%$ YEP. Swain et al. (1996) also recorded an increase in carcass protein of Cirrhinus mrigala fry fed probiotic (Bioboost Forte)-supplemented diets. However, without performing any enzymatic study, they attributed the increase in carcass protein to the improvement of enzyme activity in the gut as a result of which the nutrients were spared for the growth and overall well-being of the animal.

Some authors have hinted at the potential importance of intestinal microflora in fish nutrition (Hepher 1988, Olsen and Ring $\varnothing$ 1997). A number of factors can influence the composition of the normal intestinal microflora (Ring $\varnothing$ et al. 1995). The effect of diet on the intestinal flora depends upon biochemical composition of the diet and was investigated in endothermic animals (Coppestock and Zedd 1983, Goldin 1986, Raibaud 1988). The relationship of intestinal microflora to the food of marine fish species was reported (Sera and Ishida 1972 a, b, Sera et al. 1972). The present investigation revealed a correlation between the growth performance of Labeo rohita and intestinal bacterial count (in terms of $\mathrm{CFU} \cdot \mathrm{g}^{-1}$ ) under in vitro culture conditions (e.g. TSA, GP, ST, and CMC), which is evident from the reduced growth of rohu fingerlings fed diets containing YEP above $0.2 \%$ level (diets D3 to D5). Ring $\varnothing$ and Strøm (1994) also demonstrated the effect of diet on the intestinal microflora in Arctic charr, Salvelinus alpinus.

Another aspect to be considered is a possible contribution of the indigenous microflora to the nutritional process of fish via extracellular bacterial enzymes (Ring $\varnothing$ and Birkbeck 1999). Hamid et al. (1979) reported the production of protease, amylase, chitinase, and lecithinase by the bacteria of the genera Vibrio and Enterobacter isolated from the fish gut. Saha and Ray (1998) reported the presence of cellulolytic bacteria in the gut of Labeo rohita fingerlings. The present study suggests that the supplementation with YEP might have played an important role by providing essential nutrients, not present in the feed ingredients, through microbial action or by improving the digestive ability by activating enzymes (probably with cofactors). Therefore, the contention of this investigation with respect to the profiles of digestive enzymes (protease and $\alpha$-amylase) in the gut and the role of microbes in exogenous enzyme production seems to be substantiated. The results obtained in this study indicate the positive effect of oral administration of YEP to rohu fingerlings. The better growth performance and nutrient digestibility 
in rohu fingerlings fed YEP-supplemented diets up to a level of $0.2 \%$ might be due to the production of extracellular enzymes by the gut microflora, which helped in a better utilization of feed. However, further studies are required to characterize (physiologically and biochemically) and to identify these microorganisms prior to any fullscale application in commercial aquaculture.

\section{CONCLUSION}

The results of the present study indicate the better growth performance and nutrient digestibility in rohu fingerlings fed yeast extract powder (YEP)-supplemented diets. YEP in the diets may stimulate the gut bacterial flora to intensify production of proteolytic enzymes. The positive effect of oral administration of YEP to rohu fingerlings might be due to the production of extracellular enzymes by the gut microflora, which helped in a better utilization of feed. Higher levels of yeast extract powder resulted in a reduction in the whole body lipid content. YEP may potentially enable fish nutritionists to positively influence the autochthonous microbial populations. However, further research is needed to determine their specific effects in the nutrition of fish.

\section{ACKNOWLEDGEMENTS}

We are grateful to the Indian Council of Agricultural Research, New Delhi (Project F No. 4 (28)/96-ASR-I) and to University Grants Commission (Department of Special Assistance Programme) for financial support.

\section{REFERENCES}

Anonymous 1985. Standards methods for the examination of water and waste water. 16th edn. American Public Health Association, Washington, DC.

Anonymous 1990. Official methods of analysis of AOAC International. 15th edn. Association of Analytical Chemists Inc., Arlington, VA.

Bairagi A., Sarkar Ghosh K., Sen S.K., Ray A.K. 2002. Enzyme producing bacterial flora isolated from fish digestive tracts. Aquaculture International 10: 109-121.

Benkappa S., Varghese T.J. 2003. Isoleucine, leucine, and valine requirement of juvenile Indian major carp, Cirrhinus cirrhosus (Bloch, 1795). Acta Ichthyologica et Piscatoria 33: 161-172.

Bernfeld P. 1955. Amylase [alpha] and [beta]. pp. 149-150 In: Colowick S.P., Kaplan N.O. (eds.) Methods in enzymology. Vol. I. Academic Press, New York.

Beveridge M.C.M., Sikdar P.K., Frerich G.N., Millar S. 1991. The ingestion of bacteria in suspension by the common carp, Cyprinus carpio L. Journal of Fish Biology 39: 825-831.

Bolin D. W., King R. P., Klosterman E.W. 1952. A simplified method for the determination of chromic oxide $\left(\mathrm{Cr}_{2} \mathrm{O}_{3}\right)$ when used as an index substance. Science 116: 634-635.

Charlon N., Bergot P. 1984. Rearing system for feeding fish larvae on dry diets. Trial with carp (Cyprinus carpio L.) larvae. Aquaculture 41: 1-9.

Cho C.Y., Slinger S.J., Bayley, H.S. 1982. Bioenergetics of salmonid fishes: energy intake, expenditure and productivity. Comparative Biochemistry and Physiology B 73: 25-41.
Coppestock M.S., Zedd, A.J. 1983. Intestinal flora of infants. pp. 79-99. In: Hentgens D.J. (ed.) Human intestinal microflora in health and disease. Academic Press, New York.

Dabrowski K., Charlon N., Bergot P., Kaushik, S.J. 1984. Rearing of coregonid (Coregonus schinzi palea Cuv. et Val.) larvae using dry and live food. I. Preliminary data. Aquaculture 41: 11-20.

Dabrowski K.R., Kaushik S.J. 1985. Rearing of coregonid (Coregonus schinzi palea Cuv. et Val.) larvae using dry and live food. III. Growth of fish and developmental characteristics related to nutrition. Aquaculture 48: 123-135.

Das B.C. 1965. Yeast dosage level and the post-embryonic survival and growth of the carp Labeo rohita (Ham.). Journal of Experimental Zoology 159 (3): 405-412.

Das B.C., Krishnamurthy H. 1959a. Comparative effects of yeast, ruminant stomach extract on the survival rate of Indian carp during the first three weeks of life. Indian Journal of Fisheries 6: 211-221.

Das B.C., Krishnamurthy H. 1959b. Comparative effects of yeast, vitamin B complex and vitamin B12 on the survival rate of Indian major carp during the first two weeks of life. Proceedings of National Institute of Science, India 25: 300-306.

De Silva S.S., Anderson T.A. 1995. Fish Nutrition in Aquaculture. Chapman and Hall, London.

Duncan D.B. 1955. Multiple range and multiple $F$-tests. Biometrics 11: $1-42$.

Goldin B.R. 1986. In situ bacterial metabolism and colon mutagenes. Annual Review of Microbiology 40: 367-393.

Hamid A., Sakata T., Kakimoto D. 1979. Microflora in the alimentary tract of grey mullet. IV. Estimation of enzyme activities of the intestinal bacteria. Bulletin of the Japanese Society of Scientific Fisheries (Nippon Suisan Gakkaishi) 45: 99-106.

Hepher B. 1988. Nutrition of Pond Fishes. Cambridge University Press, Cambridge.

Jhingran V.G. 1983. Fish and Fisheries of India. Hindustan Publishing Corporation (India), Delhi.

Mahajan C.L., Sharma K.P. 1976. Studies on the effect of some vitamins and antibiotics on the survival and growth of carps in the first few weeks of their life. Journal of the Inland Fisheries Society of India 8: 192-199.

Matty A.J. 1986. Nutrition, hormones and growth. Fish Physiology and Biochemistry 2: 141-150.

Maynard L., Loosil J., Hintz H., Warner R. 1979. Animal Nutrition. 7th edn. McGraw Hill, New York.

Moore S., Stein W.W. 1948. Photometric ninhydrin method for use in the chromatography of amino acids. Journal of Biological Chemists 176: 367-388.

Olsen R.E., Ringø E. 1997. Lipid digestibility in fish: a review. Recent Research Development in Lipid Research 1: 199-265.

Philippe A.D., Langdon J.C. 1994. Use of a probiotic for the culture of larvae of the Pacific oyster (Crassostrea gigus Thunberg). Aquaculture 119: 25-40.

Pollman D.S. 1986. Recent advances in animal nutrition. Butterworths, London.

Raibaud P. 1988. Factors controlling the bacterial colonization of neonatal intestine. pp. 205-219. In: Hanson L.A. (ed.) Biology of human milk. Vol. 15. Nestle Nutrition Workshop Series, Raven Press, New York. 
Ramachandran S., Ray A.K. 2004. Inclusion of extruded grass pea, Lathyrus sativus seed meal in compound diets for rohu, Labeo rohita (Hamilton, 1822) fingerlings. Acta Ichthyologica et Piscatoria 34: 205-218.

Ravi J., Devaraj K.V. 1991. Quantitative essential amino acid requirements for growth of Catla catla (Hamilton). Aquaculture 96: 281-291.

Ringø E., Strøm E. 1994. Microflora of Arctic charr, Salvelinus alpinus (L.). I. The gastrointestinal microflora of free-living fish and the effect of diet and salinity on intestinal microflora. Aquaculture and Fisheries Management 25: 623-629.

Ringø E., Strøm E., Tabachek J-A. 1995. Intestinal microflora of salmonids: a review. Aquaculture Research 26: 773-789.

Ringø E., Birkbeck T.H. 1999. Intestinal microflora of fish larvae and fry. Aquaculture Research 30: 73-93.

Saha A.K., Ray A.K. 1998. Cellulase activity in rohu fingerlings. Aquaculture International 6: 281-291.

Salle A.J. 1974. Fundamental Principles of Bacteriology. 7th edn. Tata McGraw Hill Publishing Company Ltd., New Delhi.

Sen P.R. 1972. Effect of growth promoting substances on survival and growth of fry of Indian major carps (Abstract). p. 8. In: Proceedings of the symposium on aquaculture as an industry. Central Inland Fisheries Research Institute, Barrackpore, India.

Sera H., Ishida Y. 1972a. Bacterial flora in digestive tracts of marine fish. II. Changes of bacterial flora with time lapse after ingestion of diet. Bulletin of the Japanese Society of Scientific Fisheries (Nippon Suisan Gakkaishi) 38: 633-637.
Sera H., Ishida Y. 1972b. Bacterial flora in digestive tracts of marine fish. III. Classification of isolated bacteria. Bulletin of the Japanese Society of Scientific Fisheries (Nippon Suisan Gakkaishi) 38: 853-858.

Sera H., Ishida Y., Kadota H. 1972. Bacterial flora in the digestive tracts of marine fish. IV. Effect of $\mathrm{H}^{+}$concentration and gastric juices on the indigenous bacteria. Bulletin of the Japanese Society of Scientific Fisheries (Nippon Suisan Gakkaishi) 38: 859-863.

Singh B.N., Sinha V.R.P., Kumar K., Swamy D.N. 1986. Observations on the feed formulations and fortification of conventional fish feed for rohu, Labeo rohita and mrigal, Cirrhinus mrigala fry and fingerlings. Journal of the Academy of Ichthyology, Modinagar 7: 31-34.

Spyridakis P., Metailler R., Gabaudan, J., Riaza A. 1989. Studies on nutrient digestibility in European sea bass (Dicendrarchus labrax). Methodological aspects concerning faeces collection. Aquaculture 77: 61-70.

Steffens W. 1989. Principles of Fish Nutrition. Ellis Horwood, Chichester.

Swain S.K., Rangacharyulu P.V., Sarkar S., Das K.M. 1996. Effect of a probiotic supplement on growth, nutrient utilisation and carcass composition in mrigal fry. Journal of Aquaculture 4: 29-35.

Received: 27 May 2005 Accepted: 15 November 2005 